\title{
Development of e-medicine in the context of digitalization of the economy
}

\section{Aziza MIRZARAKHIMOVA ${ }^{1}$}

Tashkent State University of Economics

\section{ARTICLE INFO}

Article history:

Received February 2021

Received in revised form

20 February 2021

Accepted 15 March 2021

Available online

15 April 2021

\section{Keywords:}

Innovation,

digital economy,

e-health,

e-medicine,

telemedicine.
ABSTRACT

In scientific article reflected the urgency of the implementation of information and communication technologies in the field of medicine in terms of the development of the digital economy and their benefits, analyzed the situation of implementation of e-medicine in the Republic put forward proposals for the development of this sphere in Uzbekistan.

2181-1415/C) 2021 in Science LLC.

This is an open access article under the Attribution 4.0 International (CC BY 4.0) license (https://creativecommons.org/licenses/by/4.0/deed.ru)

\section{Рақамлашган иқтисодиёт шароитида электрон тиббиётни ривожлантириш}

\footnotetext{
Калит суизлар:

инновациялар, рақамли иқтисодиёт, электрон соғлиқни сақлаш, электрон тиббиёт, телемедицина.
}

\begin{abstract}
АННОТАЦИЯ
Ушбу илмий мақолада рақамли иқтисодиётни риқожлвнтириш шароитида тиббиёт сохасига ахбороткоммуникацион технологияларини жорий этишнинг долзарблиги ва уларнинг афзалликлариакс эттирилган, хамда республикада электрон тиббиётни жорий этиш холати тахлил қилинган ва Ўзбекистон Республикасида ушбу сохани ривожлантириш учун таклифлар берилган.
\end{abstract}

\footnotetext{
${ }^{1}$ Applicant of Tashkent State University of Economics, Tashkent, Uzbekistan.

E-mail: azizamirzarakhimova@gmail.com
} 


\section{Развитие электронной медицины в условиях цифровизации экономики}

\author{
Ключевые слова: \\ инновации, \\ цифровая экономика, \\ электронное \\ здравоохранение, \\ электронная медицина, \\ телемедицина.
}

\begin{abstract}
АННОТАЦИЯ
В научной статье отражены актуальность внедрения информационно-коммуникационных технологий в сферу медицины в условия развития цифровой экономики и их преимущества, проанализирована ситуация внедрения электронной медицины в республике, даны предложения по развитию данной сферы в республике Узбекистан.
\end{abstract}

Since the first days of independence, Uzbekistan has set itself the goal of building a democratic state governed by the rule of law and a fair civil society, in which the main thing is the individual, his rights and interests. Looking back at the 29-year path of sovereign development, we can say with full confidence that a huge amount of work has been done to implement socio-economic and socio-political reforms, which has led to large-scale achievements and successes in all spheres of state and society.

In February 2017, President of Uzbekistan Sh. Mirziyoyev signed a Decree "On the strategy of actions for further development of the Republic of Uzbekistan in 2017-2021". The document, which includes 5 priority areas for the country's development for five years: improving public administration, the judicial and legal system and the social sphere, liberalizing the economy and ensuring security, was developed based on the results of studying issues of concern to the population, analyzing current legislation, law enforcement practice and foreign experience [1].

In the modern economy, innovations are becoming the main factor in improving the efficiency of not only all sectors of the economy, but also social structures-education, medicine, and public administration. An innovative way of development is the only possible way to build a competitive economy of the country as a whole.

Given the current situation, a specific characteristic of the economy is the strengthening of the role of information and communication technologies (ICTs) in all spheres of life of the population, which in turn leads to the expansion of social interaction - electronic participation of civil society in the discussion of state initiatives. The problem of introducing the digital economy in Uzbekistan has become particularly relevant. In order to further develop the economy on an innovative path, President Sh. Mirziyoyev declared 2020 the "Year of development of science, education and the digital economy". "It is known that digital technologies not only improve the quality of products and services, reduce costs, but also are an effective tool in the fight against corruption - the most serious problem that concerns me very much" [2], the President stressed, recalling that the introduction of digital technologies contributes to the efficiency of state and public administration, the development of the social sphere.

As the experience of foreign countries shows, the introduction of information and communication technologies in all spheres of life gives citizens access to high-quality services of government agencies and at the same time reduces the cost of these services. One of these services is an electronic health service. E-medicine includes a set of organizational and technological tools that increase the availability and quality of medicine by realizing the potential of information and communication technologies (ICTs). 
ICTs create opportunities for remote provision of highly qualified medical care, monitoring of patients' health, conducting medical research, organizing remote consultations of doctors, issuing sick lists and receiving prescriptions in electronic form, and for other ways of useful use of modern technologies in medicine.

Today, there are many examples where innovations in the field of e-medicine significantly facilitate access to medical services and make them more convenient. For example, a number of countries already have online services that allow you to get medical care at any time via the Internet, consult a doctor, write prescriptions, etc. For example, analysts estimate that the global telemedicine market was $\$ 14.3$ billion in 2014 and will grow to $\$ 36.6$ billion by 2020 . At the same time, the largest area will be the most innovative sphere of telemedicine-health monitoring [3].

Thus, the experience of foreign countries demonstrates a significant interest in the development of health information systems, their widespread implementation and widespread use. At the same time, these countries are aware of the need to further improve their organizational systems in order to adapt them to modern telemedicine technologies.

Observing global trends, Uzbekistan has also taken the first steps to develop ehealth. The decree of the President of the Republic of Uzbekistan "on comprehensive measures to radically improve the health system of the Republic of Uzbekistan" dated December 7, 2018 approved the Concept of development of the health system of the Republic of Uzbekistan for 2019-2025. The concept pays special attention to the wide implementation of the "E-health" system, the creation of a complex of information systems and databases integrated on the basis of common national standards [4].

At the same time, we believe that in order to successfully implement e-health and reduce health inequalities in the development of digital services, close attention should be paid to improving digital and health literacy among health workers and the population.

It should be noted that it is advisable to expand the e-learning program for both students and healthcare professionals. Universal health coverage directly affects the health of the population and is a characteristic sign of the state's desire to support the well-being of the country's population. According to WHO, universal access reduces widespread poverty and social inequalities, improves education, helps ensure sustainable development, and enables citizens to actively contribute to the well-being of their families and communities, thereby empowering people to be healthier, more productive, and more involved in protecting their health and well-being [5].

It should also be noted that e-health plays a unique and crucial role in achieving universal health coverage. E-health allows you to expand the range of health services, increase the transparency and accessibility of preventive care and medical information, expand the base for using the offered health services, and stimulate innovation and efficiency growth.

In General, we believe that in order to achieve the goals set for the development of e-medicine as soon as possible, it is necessary to introduce the services of "smart medicine", remote prevention and treatment, and "e-medicine". But first, we need to develop the necessary training programs for the development of information literacy of future medical workers, and create training courses to improve the skills of employees in this field using IT programs. 


\section{REFERENCES:}

1. Указ Президента Республики Узбекистан от 22.01.2018 г. за № УП-5308 «0 государственной программе по реализации стратегии действий по пяти приоритетным направлениям развития Республики Узбекистан в 2017-2021 годах в «Год поддержки активного предпринимательства, инновационных идей и технологий» // «Народное слово», 2018 г., 23 января.

2. https://www.podrobno.uz/ 24 января 2020, 12:20.

3. Журавлев М.С. Электронное здравоохранение: становление и развитие // Право. Журнал Высшей школы экономики. 2016 - № 2. - С. 235-241.

4. Указ Президента Республики Узбекистан «О комплексных мерах по коренному совершенствованию системы здравоохранения Республики Узбекистан» от 7 декабря 2018 года. https://www.who.int/dg/speeches/2018/pandemic-free-world/ru/ 